\title{
安全支援システム導入実績
}

王子板紙株式会社 岐阜工場 工務部 横山 裕, ○古井 勝志

\section{The Introduction of the Safety Support System}

Yutaka Yokoyama and OKatsushi Furui

Gifu Mill, Oji Paperboard Co., Ltd.

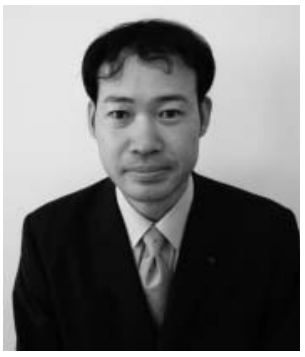

古井勝志

\begin{abstract}
The DCS of The Ena factory was renewed to “CENTUM CS 3000" that was the latest model in 2005. The improvement of the DCS operativeness in the manufacturing premise and the maintenance of the watch environment were achieved by this update. It improved the efficiency of the field operation by these. Then, we examined what DCS could be operated by the wireless system. Wireless LAN network decided to be constructed in the factory, and we started development a mobile DCS. Mobile DCS is a system by which the operation and the watch of its own plant become possible. If it is a range where the electric wave of wireless LAN reaches, we can operate it from tablet PC and the portable terminal. As a result, the operation of the plant by the few people became possible. However, the problem was caused that worker's position in the site including patrol was not able to be recognized. The safety support system from which the worker acquired information. . the address and the movement of the body (state of the acceleration).. now was introduced from a wireless terminal by the cooperation of Yokogawa Electric Corporation.
\end{abstract}

分類 $: V_{2}$ 紙パルプ工程制御システム, $\mathrm{V}_{0}$ その他

\section{1.はじめに}

王子板紙(株)岐阜工場は, $12 \mathrm{~km}$ 程離れた中津川工場と恵 那工場とを組織統合したうえで，一体運営を行っている。

恵那工場は, 横河電機製 DCS「CENTUM V」による操 業を 1985 年から行っていた。DCSの老朽化及び要員活性 化工事に伴い，2005 年に最新機種である「CENTUM CS 3000」への更新を実施した。このスケジュールにあわせ現 場レベルでの DCS 操作監視環境の実践, 及び現場操業の 効率化を図った。

当初の計画では, 各フロアーに簡易操作室を設置し, DCS の操作監視を行うべく有線 LAN の敷設を検討していたが 専用ケーブルの引き込み, 各操作室の連携などに設備費が 膨大となり，作業性も悪化する懸念が出てきた。そこで, 工場内に無線 LAN 網を構築しワイヤレスでの操業が出来 ないか検討を進め，モバイル DCSの導入に至った。また， 中津川工場も 2006 年要員効率化工事に併せ, 「CENTUM
CS 3000」を原質設備に導入, 恵那工場同様に現場での作 業性の向上を図った。

モバイル DCS は無線 LAN 網の電波範囲内であれば夕 ブレット PC, 携帯端末よりプラントの操作・監視が可能 となるシステムである。これにより, 少人数による操業が 実現した。しかし，パトロールをはじめとした現場作業で の操業者の位置管理が出来ないという問題が生じた為, 横 河電機との協業により無線端末から操業者の現在地や状態 の情報を取得する安全支援システムを導入した。本稿では このシステムについて報告する。

\section{2. 安全支援システム導入の背景}

中津川工場では，「品質・操業安定化対策工事」におい て，原質の DCS 化工事を完了した。その結果，原質・調 成係の少人数による操業となったことから，パトロール， 点検および突発故障時の対応等, 現場での 1 人作業が不可 欠となった。特に夜勤時の作業は, 他作業者との連絡は可 
能でも作業中の行動・安否については確認する手段がない 状態である。

そこで無線端末を使用したシステムを導入し，誰が何処 にいて，今どんな状態であるかをリアルタイムで確認を行 えるよう，安全支援システムを導入した。

\section{3. 安全支援システムとは}

\section{1 特 長}

安全支援システム (写真 1) の特長は以下のとおりである。 作業者の状態を遠隔でリアルタイムに確認できるため, 異常発生時の迅速な対応が可能である。作業者からの自発

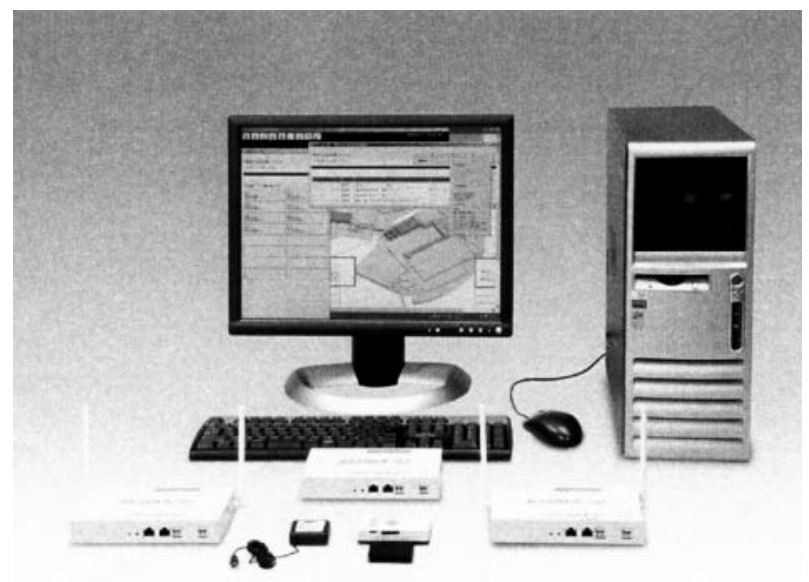

写真 1 安全支援システム PM 100
的な緊急発報通知（緊急通知ボタンにより）が可能である。 作業者の位置情報の無線基地局単位（半径約 $30 \mathrm{~m}$ ）での 把握が可能である。ネットワークを利用したシステムであ り，他のシステムとの連携が可能である。

\section{2 システム構成}

図 1 に，安全支援システム (以下，本システム)の構成図 を示す。本システムは，作業者の腰に装着する小型軽量の センサタグ，センサタグとの無線データ送受信を行う無線 基地局，センサタグと無線基地局の状態を監視して管理サ ーバにデータを伝送するシステムコントローラ，およびセ ンサタグや無線基地局の状態を表示するとともに操作・管 理画面を備えた管理サーバとクライアントから構成される。 センサタグは作業者の動き（状態）を検知し, 定周期で 状態データを無線基地局へ無線送信する。

\section{3 システム構成機器}

\subsection{1 センサタグ}

センサタグは, 作業者の腰ベルトを利用して装着する (写真 2)。センサタグには加速度センサ, 押しボタン, ブ ザーが搭載されており，加速度センサのデータを演算して， 「静止」「歩行」「走行」「臥位」（作業者が意識的に寝こ ろんでいる状態）の各状態を判定し定周期送信する。「臥 位」状態が一定時間以上継続すると，「転倒」と判定され る。さらに, 作業者が自発的に通知できるよう，「緊急」通 知ボタンが用意されている。

\subsection{2 無線基地局}

無線基地局とセンサタグとの無線通信可能な距離は, 屋

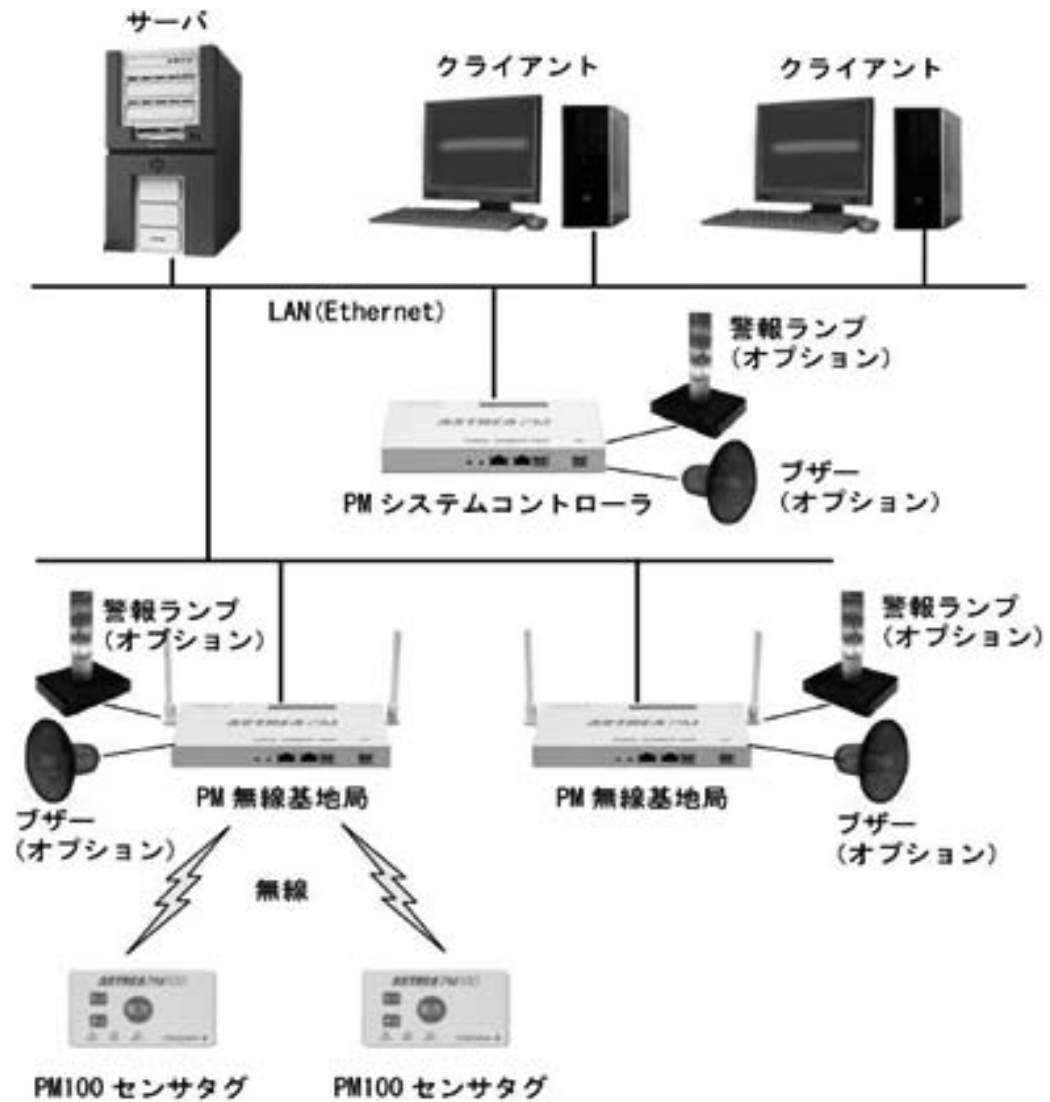

図 1 安全支援システム構成図 


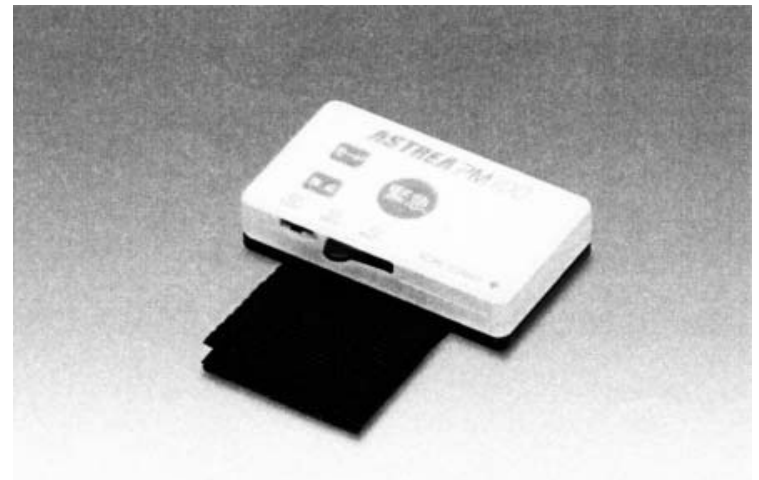

写真 2 センサタグ

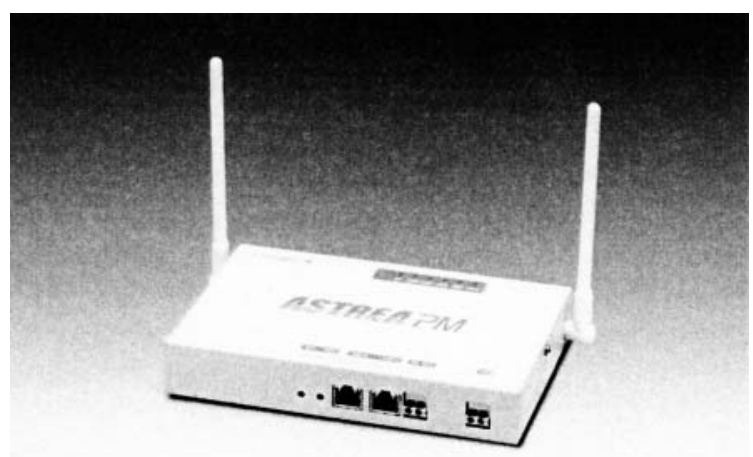

写真 3 無線基地局

内でおよそ $30 \mathrm{~m}$ である（写真 3）。適用エリア内において は, センサタグとの無線通信強度が, ある一定のレベルを 保つように設置する。

無線基地局にはリレー接点出力が搭載されており，異常 発生エリアにいる作業者に, 警告装置 (ランプやブザー等) で異常の発生を通知することができる。

\subsection{3 システムコントローラ}

システムコントローラは, 無線基地局から送られてきた 状態データをセンサタグ情報として保存し管理サーバから の要求に対して,保存されているセンサタグ情報を送信する。

「臥位」状態が一定時間以上継続した場合は，システム コントローラにて作業者が「転倒」（＝異常発生）したと 判定し, 管理サーバおよび無線基地局に異常通知を行う。ま た異常の発生を，他の作業者に通知することも可能である。 システムコントローラにはリレー接点出力が搭載されて おり, 作業者に異常が発生すると, システムコントローラ が設置されている部屋の監視員に対して，警告装置（ラン プやブザー等）で警報の発生を通知することができる。無 線基地局の稼働状態監視を行っている。

\subsection{4 管理サーバ}

管理サーバは，システムコントローラからセンサタグ情 報を収集し，データ保存を行う。

管理サーバには，センサタグの利用者情報（会社・所属・ 氏名等）を予め登録しておき，監視クライアントから，状 況の確認が行える。さらに, 異常発生履歴を保存しておく ことで，過去情報の検索・閲覧を行うことができる。

\subsection{5 監視クライアント}

監視クライアントは, Web ブラウザ経由で，管理サー バの画面を表示する機能を持つ。オペレーションウィンド ウから，ウィンドウ上の各アイコンにて各情報画面へ展開 する。

\section{4 岐阜工場における導入事例}

中津川工場への安全支援システム導入において，2 度に わたるサイトサーベイを実施し設置したい（管理したい） 設備（例．マシン，パルパー等）での無線強度の測定を行 った。図 2 はサイトサーベイ参考図である（サイトサーベ イ報告書より抜粋)。

サイトサーベイの結果から 14 台の基地局から構成され るシステムを導入した（図 3）。

設置状況から，作業者の所在，状況を確認するために， グラフィック画面を作成した（図 4)。このグラフィック 画面により，工場内の作業者所在の安全管理が管理サーバ および監視クライアントの設置されている場所にて確認が 行えることとなり, 異常時 (通報時) には対象箇所のエリ ア枠が点滅し異常を知らせることができる。また異常時に はマシン 2 階に設置されたパトライトにて他の作業者への 通知が可能である。

本グラフィック画面は，ネットワークを利用すれば，他 のクライアントからも参照が可能である。

\section{4. 導入効果}

\section{1 効果}

安全支援システム導入により従来，管理作業者は，作業 者の位置や状態など確認する手段を内線電話やトランシー バーのみで伝達を行っていたが常時確認していないため状 態の把握が行えなかった。

導入後は，作業者の位置を一括把握することで管理作業 者の負荷軽減につながった。

現在，緊急時の警報発報例は無いが発報情報を基に万が 一の事故発生時に管理作業者や対象者とは別の作業者に, いち早く緊急通報で伝えることが可能となり，合わせて作 業者の位置情報を把握できることにより，事故発生時に早 急な対応が可能となった。

また，作業者がセンサタグを身につけることにより，無 事故への意識改善や万が一の事故発生時に早急な対応が可 能ということから高い安心感も生まれた。

\section{2 所在確認の結果と改善}

所在確認については，調成室および原質については，1 階と 2 階に無線基地局を複数個（エリア分けのため）設置 する構成となった為, センサタグの位置が作業者の動きに より階をまたいだ形で検出される状態が発生した。

メーカーにて原因を調査，無線強度および無線基地局の 設置位置と工場の建築構造 (空の位置, 階段の吹き抜け等) から無線の回り込みによる現象と判明した。無線基地局側 の機能として設置フロア情報からの判断機能を追加して対 応とした。

以上の対応から, 所在位置の誤報については改善され, 作業者の移動状況や状態情報が正確にグラフィック画面で 

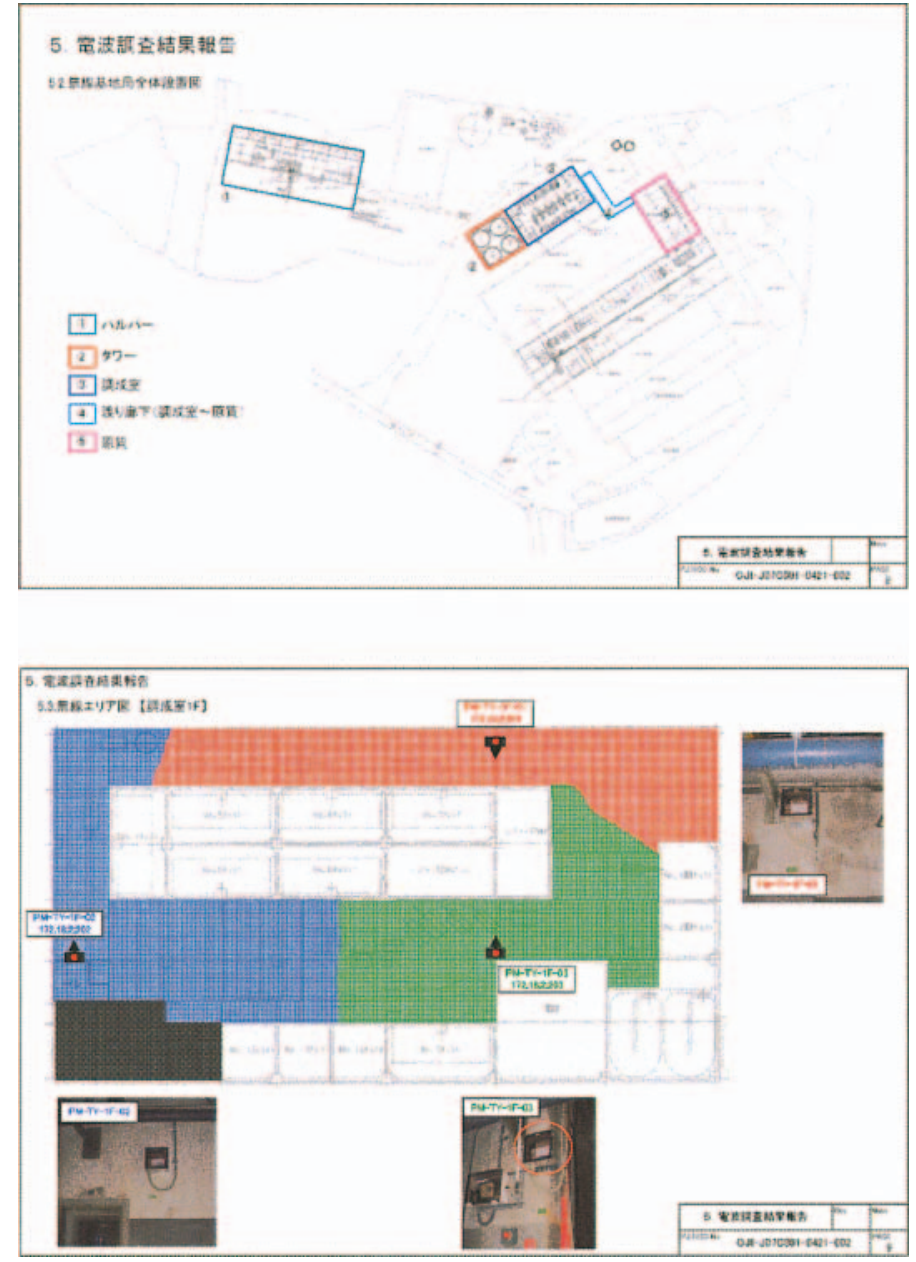

図 2 サイトサーベイ参考図

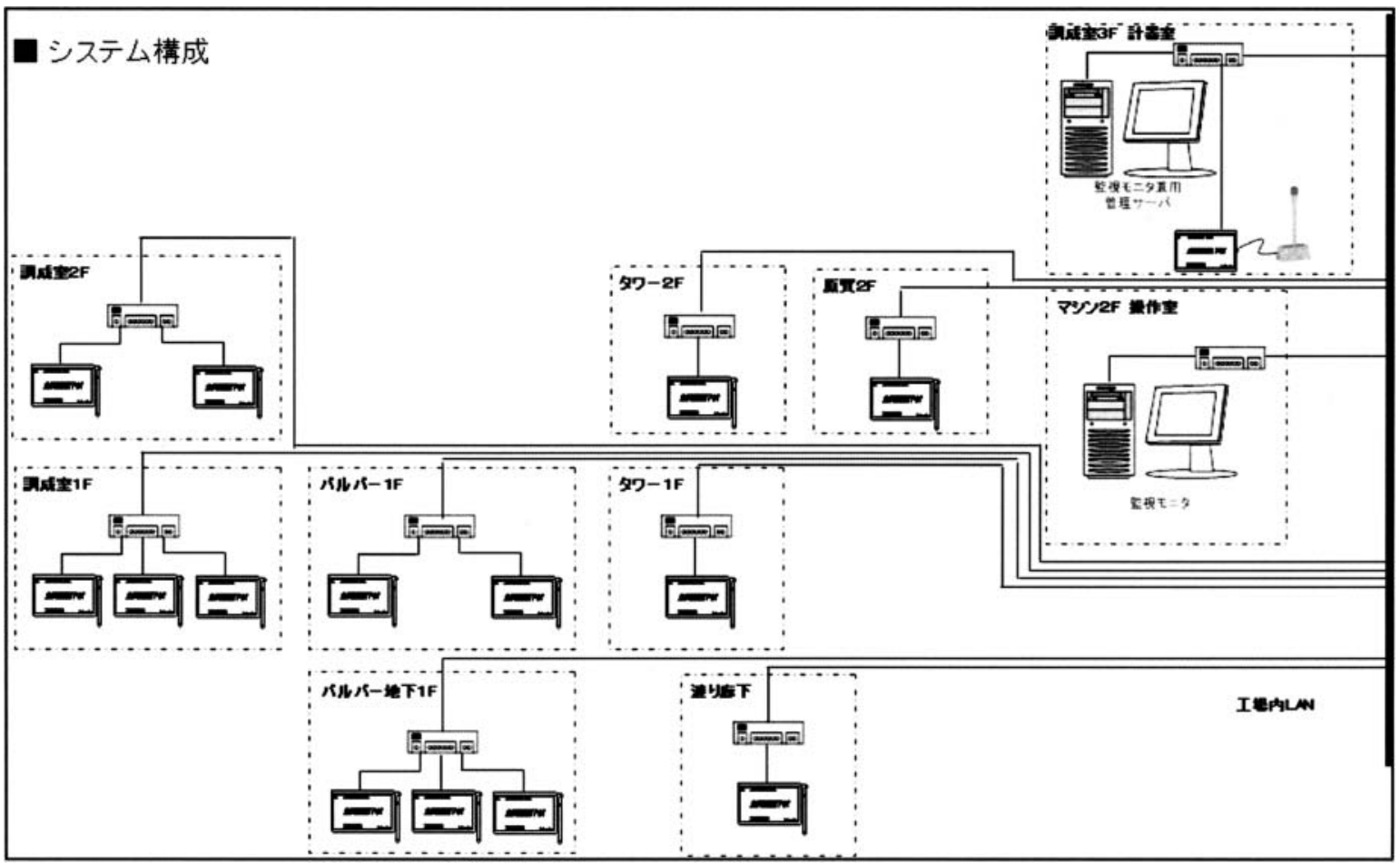

図 3 システム構成図 


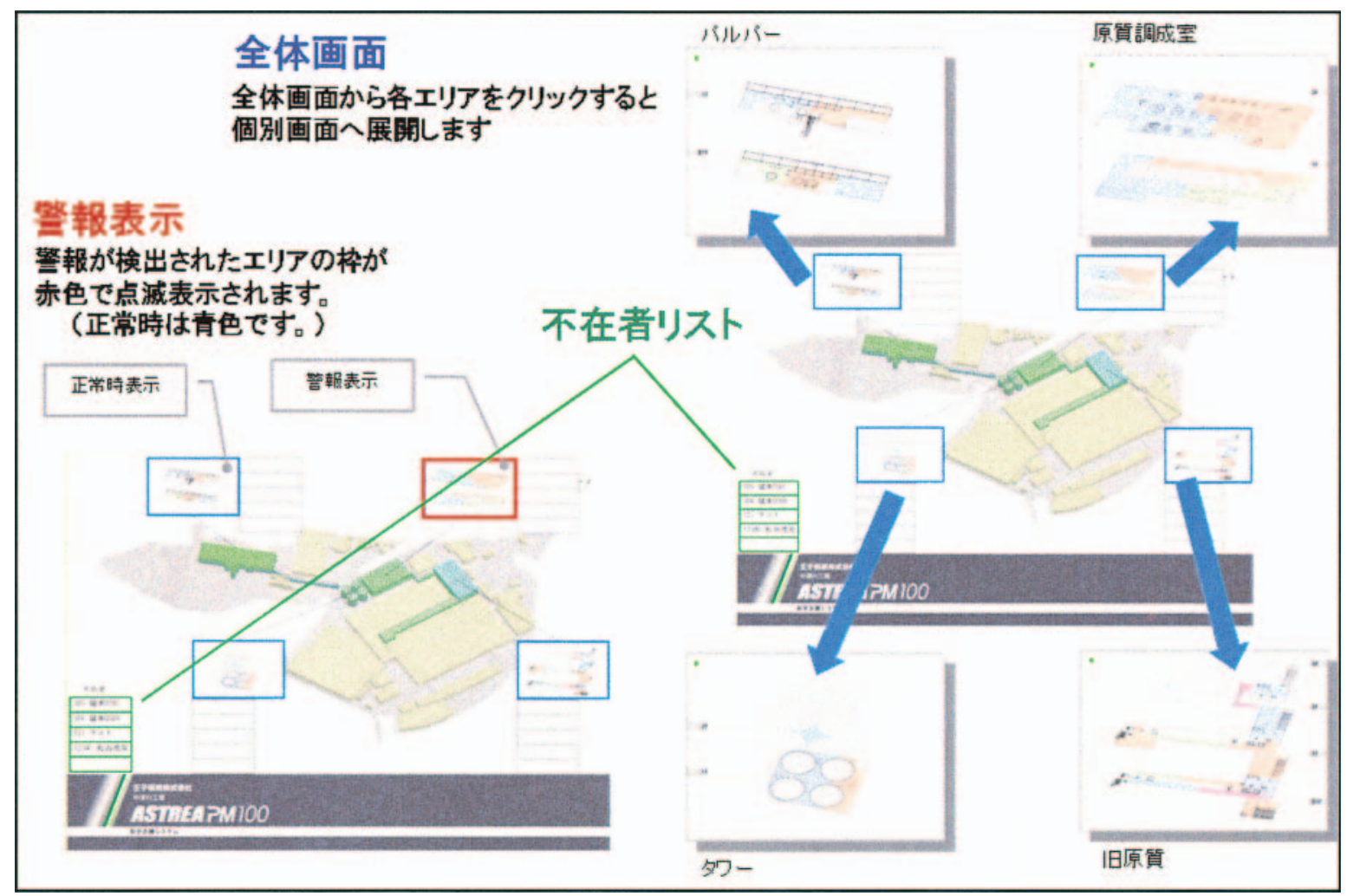

図 4 グラフィック画面展開図

確認できることとなった。

\section{5. 今後の期待}

\section{1 画面内容の充実}

現在のグラフィック画面では，画面上で確認できる情報 が，作業者・状態・緊急の項目でしかないが，今後はその エリアに入室した時刻扔よび所在時間といった情報も表示 が可能となるようにしたい。これは，センサタグが何らか の影響による故障や人がセンサに覆いかぶさる事などで電 波が途切れ連絡がとれない場合，軌跡情報から作業者の行 方を絞り込む上でも重要になる。

\section{2 無線基地局／センサタグの機能向上}

現在の無線基地局において, 電源と有線 LAN について は，別系統での配線が必要となるため設置工事の負担が大 きい, 一般的な無線機器と同様に $\mathrm{PoE}$ 機能 (LAN 配線に よる電源供給機能）を実装して LAN 配線からの電源供給 を実現してもらいたい。

また，センサタグにおいても現在のブザーによる通知方 式のみでなく簡易な液晶表示㧍よびバイブレー夕機能によ る通知方式も可能となるよう要望していきたい。

\section{3 総合的な課題}

岐阜工場においては，モバイル DCS・安全支援システ ム，共に無線を使用したシステムとなっているがシステム 導入の際，各システムに扔いて専用アンテナ(無線基地局) の設置が必要となるため，その都度，設備費（工事費）が 発生し設置場所においても同一の箇所に複数の専用アンテ ナ（無線基地局）が設置されることとなる。
そこでメーカーには，アンテナ（無線基地局）の統合化 を図り，システムの種類に関わらず活用できるよう開発に 取り組んでもらいたい。

また，無線 LAN アクセスポイント，アンテナ設置の際， 事前に工場内のサイトサーベイをメーカー側に行ってもら うが，混信や干渉され易い周波数帯を利用するため安定性 に不安がある事などから調查時間がかかると共に調查コス 卜もかかり増設の都度, 負担になっている。そこで客先で の調査が簡単に行えるようなツールの開発を打願いしたい。

\section{6. おわりに}

今回は安全支援システム導入の過程とその使用状況につ いて報告した。

安全支援システムは，省人化に伴う現場作業においてオぺ レーターの安全確保を行い, 事故発生時に速やかな, 通知, 事故発生場所の確認を図れるなど，当工場にとっては非常 に有益なシステムである。運用開始から 14 か月が経過し た現在，安全支援システムはオペレーターにとって必要不 可欠な装備と言われるまでになった。

幸いなことにシステム導入から現在まで危険事故につい て発生はしていないが，今後も，事故発生の可能性のある 筒所（倉庫等）へ順次，基地局の設置を行っていきたい。

安全支援システムについては，今後は操業者に限らず， 電気・計装・機械保全担当者にもパトロール業務等で現場 に出向く時にセンサタグを身につけ，一人作業時の安全確 保に取り組んでいきたい。 